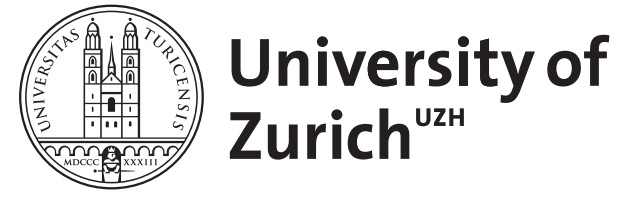

\title{
Are collectors the real looters?
}

Isler-Kerényi, Cornelia

\begin{abstract}
More on the vexed question of collectors, looting, and on the right relationship between museums, researchers and the antiquities market.
\end{abstract}

DOI: https://doi.org/10.1017/s0003598x0004669x

Posted at the Zurich Open Repository and Archive, University of Zurich ZORA URL: https://doi.org/10.5167/uzh-155373

Journal Article

Published Version

Originally published at:

Isler-Kerényi, Cornelia (1994). Are collectors the real looters? Antiquity, 68(259):350-352.

DOI: https://doi.org/10.1017/s0003598x0004669x 
was found, accompanied by details of its former context to provide the basis for its interpretation, were the identifying characteristics of a modern scholarly collection, and high-quality documentation took precedence over the visual attractiveness of a particular object.

Cultural orphans, torn from their contexts, remain for ever dumb and virtually useless for scholarly purposes. Mere appreciation of visual attractiveness, and the aesthetic pleasures to be derived from high-profile objects, must not be confused with knowledge or depth of understanding of them, and here the influence of the Modern Movement in the Fine Arts with its cult of the art object bereft of intellectual content - Roger Fry's 'form without content' - has been pernicious. Nevertheless, this way of thinking has been an important component in the institutional schizophrenia demonstrated by many major museums in the United States of America when they acquire high-profile antiquities with no provenances as 'specimens of ancient art' and ignore their dubious status as archaeological specimens.

The ability and willingness of those museums, and like-minded private collectors, to pay top-of-the-market prices for such antiquities fund the illicit market structure extending down to the bulldozer operators in the Lebanon and those with rock-saws in the jungles of Central America. With the adoption of more rigorous collecting policies in those flagship museums one key component in the future management of the antiquities market is put into place. The return of the so-called Lydian
Hoard to Turkey is in this respect a step in the right direction.

However, a change of collecting policies at the top is not in itself sufficient to impose fundamental changes on the operations of the antiquities market, and consequently the future lies more in using the mechanism of the market place itself to create a trading environment which finds illegally excavated, stolen and unlawfully exported cultural property less profitable and thus less attractive. Integral to this approach is the creation of a substantial and growing price differential between documented and undocumented objects passing through the market. This concept is very attractive, not least because once that price differential begins to be established and generally recognized, the documentation of the object has acquired an independent pecuniary value and, without fresh legislation, the market itself will from then on police it internally. If the documentation sold with an object subsequently proves to be false or incorrect in any significant respect, the purchaser can under the existing legislation make a claim on the vendor in respect of the overall reduction in pecuniary value as against the total price paid for object+documentation. Just as the contractual relationships between vendors and purchasers already cover the accuracy of the description of the goods, the corpus of documentation accompanying an object and justifying a higher price will fall into precisely the same category as soon as it possesses a definable pecuniary value of its own.

\section{Are collectors the real looters?}

\section{CORNELIA ISLER-KERÉNYI*}

\section{More on the vexed question of collectors, looting, and on the right relationship between museums, researchers and the antiquities market}

'Collectors are the real looters': under this ti-
tle, Colin Renfrew replied to one of the harsher
reviewers of his book on the Cycladic idols of
the Goulandris Collection (1993: see also
Broodbank 1992). The discussion has since been enriched, historically and methodologically, by David Gill \& Christopher Chippindale in an extended study (1993), which makes it

* Archäologisches Institut der Universität, Rämistrasse 73, CH-8006 Zürich, Switzerland. 
possible for lovers of Cycladic culture, and archaeologists who do not specialize in it, to comprehend the at times devastating interaction between illegal excavations in the Aegean, the art market, collectors and museums - mechanisms which have not only spoiled, utterly and for ever, our knowledge of an entire culture, but which have exercised a tendentious influence on the formulation of research.

As we all know, and as Gill \& Chippindale (1993: 603, 640, 653) remind us, the theme could be extended to areas of central importance in Classical Archaeology, such as iconography, or the study of Attic and South Italian pottery. Here too the question arises whether, under the influence of collecting and the market, specialized lines of research like painterattribution may not be winning favour at the expense of others that are founded on the evaluation of find-contexts; and whether they may not be thereby alienating this discipline, which has its own culturally aware public, from field archaeology and narrowing it down to an academic game.

But the occasion for these lines is that Renfrew's title, used without a question-mark, provokes objections. Certainly the collectors cannot be entirely acquitted of responsibility for the evil of looting, any more than can the art market, the museums or, come to that, the Classical Archaeologists. These interactions are now vividly exposed in the travelling exhibition 'Provenance: unknown. Looting destroys the archaeological heritage' (see the illustrated catalogue, Graepler et al. 1993). Quite apart from this, the countries of origin of the illegally excavated objects are not entirely guiltless, by mid-direction or default, of making this sorry state of affairs possible.

One could weigh up these various responsibilities precisely against each other in order to construct a 'hierarchy of guilt' - an uncongenial and, above all, an unhelpful activity. But at the end, the collectors would be less badly placed than other links in the sorry chain. The problem is notoriously rooted in 200 years of archaeological history and, at bottom, in that idealized picture of antiquity which, from Winckelmann to the present day, has provided such great (and often positive) stimulus to the history of ideas and to Classical Archaeology.

Yet this does not mean that things should simply be allowed to continue as they are.
There is a need felt on all sides for the situation to be clarified, so that scholarship, museums, collectors with a genuine interest in art and culture, and an antiques trade with a real sense of responsibility, can collaborate and advance under better conditions.

From his own considerations, Renfrew (1993: 17) reaches the following conclusion: 'The ultimate aim, of course, would be to bring about some reduction in the commercial demand for looted antiquities' - a conclusion that will find support even among those with only an inexpert knowledge of the workings of the market economy. The next question is therefore: how would an antiques market look, that dealt only in the holdings of existing collections? Actual examples exist. Comparable markets, which are based on material that is in principle restricted and are thus not growthoriented, can be found for instance in antique carpets (Stahr 1993), and in Chinese pottery, including porcelain (Prof. H. Brinker (Zürich) pers. comm.). In both cases, markets can be accounted healthy and the risk of fakes is no great threat to the expert, who can now fall back on scientific dating methods. Since the materials are in short supply one can obviously not count on any growth worth mentioning in the clientèle; and yet, it seems, the dealers get their money's worth. In Stahr's words, 'it is precisely the sluggishness of the supply and the consequent scarcity of the material which act as stabilising elements for market and prices'.

In the special case of classical antiques, there exists a further problem: that there are buyers who, as events at recent auctions have shown, are prepared to pay excessive and disproportionate prices for ancient works of art. Some vases from the Hirschmann Collection put up for auction in London at top prices in January 1994, were then offered in February at the 34 th Swiss Art and Antiques Fair (KAM) in Zürich. Thus high prices are being consciously generated today, in turn provoking speculation with finds and the activity of illegal excavators. (On the other side, the policies of 'the world's richest museum, the Paul Getty Museum in Malibu, California' (Schenk 1993: xxx) have in recent years shown signs of a reorientation (True 1992).) This puts at a disadvantage those buyers (private collectors as well as museums) who, with their own individual line and with limited means, operate in a selective and not 
in a speculative way; and thus spoils the working of a healthy, if limited, market. So we come to the question: would it not be possible to follow initiatives already formulated (Pallottino 1992) and, instead of spending such gigantic sums on the acquisition of single works of art, to devote them to long-term loans of objects, to the care and study of original material or the conservation of monuments in situ, to help with the protection of archaeologically and environmentally sensitive landscapes in economically disadvantaged countries, to the

\section{References}

Broodbank, C. 1992. 'The spirit is willing', Antiquity 66 : $542-6$.

Gill, D.W.J. \& C. Chippindale. 1993. Material and intellectual consequences of esteem for Cycladic figurines, American Journal of Archaeology 97: 601-59.

Graepler, D., et al. 1993. Fundort: unbekannt. Raubgrabungen zerstören das archäologische Erbe, mit einem Vorwort von Paul Zanker. (Contact address: D. Graepler, c/o Archäologisches Institut, Marstallhof 4, D-69117 Heidelberg, Germany; Archäologisches Institut der Universität, Rämistrasse 73, CH-8006 Zürich, Switzerland.)

Pallottino, M. 1992. Resolutionen der Internationalen Tagung 'Roma e le capitali europee dell'archeologia' vom June 1991, Eutopia 1(1): $114 f$. training of local academic and conservation experts?

The more that the policies of significant buyers and public archaeological museums were so redirected, the greater would be the room to move in the market for those private collectors who share with archaeologists an interest in past cultures and ancient art. A stimulating dialogue, which has for 200 years been of benefit to the broader public understanding of the ancient world, could be continued in an atmosphere of reciprocal trust.

Renerew, C. 1993. Collectors are the real looters, Archaeology (May/June): $16 f$.

Schenk, R. 1993. 'All is pretty' (Andy Warhol): eine Betrachtung über die Bedeutungsentwicklung der Kunst, Katalog der 34. Schweizerischen Kunst-und Antiquitätenmesse in Zürich im April 1993: xxi-xxxii. M"nchen: Weltkunst Verlag.

STAHR, V.S. 1993. Der Handel mit antiken Teppichen und Textilien ein kleiner, aber feiner Markt, Neue Zürcher Zeitung $253(30 / 31.10 .93): 15$. (Kunsthandel, Auktionen).

TRUE, M. 1992. Recognizing responsibility: some positive and negative contributions of archaeological museums abroad to the preservation of cultural properties and proposals for the future, Eutopia 1(1): 75-82. 